\title{
ヒドラの散在神経系の神経生物学
}

小泉 修*

動物界で最も単純な神経系をもつ腔腸動物の中で 特に細胞生物学的な知見の豊富なヒドラを中心に, 散在神経系を解説する。その神経系の構造(解剖学) ・ 機能(生理学・行動学) ・形成(発生生物学)を解説す る。

この単純な神経系も, 電気伝導・化学伝達のよう な基本的な神経系としてのセットは，兼ね備えてい る。しかし，脳のような発達した神経集中を持たな い散在神経網である。個々の神経細胞は, 全て感覚 ニューロンであり運動ニューロンであり介在ニュー ロンであり神経分泌細胞であって，多機能的である。 神経細胞は，成熟個体においても常に幹細胞より 分化・生産され続けていて, 同時に, 体の先端より 抜け落ちている。頭部を切除すると, 数日内に頭部 組織が再生すると同時に頭部に特異的な神経網が再 現してくる。

神経機能を見ると, 行動学的には高等動物では中 枢神経系が行う各種の機能を示す。飽食による各種 行動修飾, 2 種以上の感覚入力の統合による行動決 定，原始的な学習である慣れなどの中枢機能を示す。 同時に，散在神経系ならではの地方分権的な神経機 能も見られる。

集中神経系での神経細胞の様々な特殊性として, 発生初期での神経細胞の増殖能・分化能の襄失, 回 路維持の為の神経細胞の長期生存, 神経細胞の極性 (情報入力側としての樹状突起と出力側としての軸 索)，アミン類・アセチルコリン類・アミノ酸類を 中心にした情報伝達, などが常識化している。これ に対して, 散在神経系では, 神経細胞の継続的な生 産, 神経細胞の激しい入れ替わり, 樹状突起と軸索 の区別の付かない神経突起, ペプチド類を主にした 神経伝達,で対比される。

現存する多様な神経系を単純なものから複雑なも のまで系統樹に従って並べて，一番単純なものから
眺めてみると, 比較神経生物学の様々な新しい視点 が得られる。そして，その視点はこの地球上に神経 系が現れて変化していった, 神経系の起源と進化の 過程についても何らかのヒントを与えるものかもし れない。

1.はじめに

ヒドラは腔腸動物の中の刺胞動物門のヒドロ虫類 に属し, 腔腸動物の中で最も単純な体制を持つ動物 グループである。淡水産の小動物で, 再生・出芽な どの現象により古くから実験動物の対象であった。 その為, 発生生物学的, 細胞生物学的知見が腔腸動 物の中では飛び抜けて豊富に蓄積している ${ }^{9)}$

系統樹の上では, 単細胞の原生動物の次に二胚葉 性の海綿動物があり，その次に刺胞動物門が現れる。 個体性がはっきりした二胚葉性の真の多細胞生物の 出現である。器官としての神経系もこの動物から出 現する。

ヒドラの体制は単純で, 内肧葉と外胚葉の二層の 上皮細胞で体ができていて，内外上皮層の間は， mesoglea と呼ばれる非細胞性の間充織が存在する。 体は，両端が閉じた管で，一方の端が頭部で口丘と 6 本前後の触手でできていて, 一方の端は肉茎と足 盤よりなる足部になっている。その中間か胴体部で, 胴体部と肉茎の間に出芽部がありそこから出芽によ る無性生殖が行われる。

ヒドラの上皮細胞は，その基部に筋肉繊維を持ち， 筋肉細胞としても機能している。外胚葉は縦走筋で, 内胚葉は輪状筋で, 前者が収縮すれば体が縮み, 後 者が収縮すれば体が伸びる。神経細胞は, 上皮細胞 層に存在し, 神経突起は上皮細胞の筋肉層の上を走 る。

ヒドラは, 一個体が約10万弱の細胞を含むが, 細

*Osamu KOIZUMI, 福岡女子大学人間環境学部( ₹ 813-8529 福岡市東区香住ヶ丘1-1-1) 
胞種は少なく，6種類に分けられる。外胚葉の上皮 筋細胞, 内胚葉の上皮細胞である消化細胞, 神経細 胞, 刺胞動物門に特徵的な効果器細胞である刺胞細 胞, 内胚葉で消化液を分泌する腺細胞，未分化な間 細胞, これで全てである。

細胞系譜は， 3 種に分けられ，外胚葉上皮細胞系 列, 内胚葉上皮細胞系列, それに, 間細胞系列であ る ${ }^{6)}$ 。間細胞系列は, 多分化能幹細胞である間細胞 とその分化産物である神経細胞・刺胞細胞・腺細胞・ (有性状態になった場合は, 卵や精子も), それと発 生中間体を含む。間細胞は正常な状態では, $60 \%$ を 自分の細胞プールのために使い(self renewal), 30 \%を刺胞細胞の分化に, $10 \%$ を神経細胞の分化に振 り分けている ${ }^{8)}$ 。頭部再生のような非常事態では, 神経細胞への分化の割合を増やす。このように, ヒ ドラの間細胞系列の系は, 幹細胞の決定 ·分化の制 御機構の研究のモデルシステムとして良く研究され ている ${ }^{4,6)}$ 。

\section{2. 散在神経系の構造}

散在神経系は，神経節や脳のような発達した神経 集中は見られず，体全体に網目状神経ネットワーク を形成している。体じゅうに神経細胞の細胞体と二 極性あるいは多極性の神経突起による神経網が見ら れる。ただ，形態的には，高等動物で見られる樹上 突起(dendrite) と軸索(axon)の区別は見られず, 神経突起(neurite)のみである。

超微細形態的観察では, 神経突起には, 上皮細胞 の筋肉繊維とのシナプス, 神経細胞同士のシナプス が存在することがわかる。シナプス部位には前部と 後部の濃い膜が並行に走り, 前部の方にシナプス小 胞が見られる。ただ, 小胞の数が数個と少数で, 大 型の有芯小胞のみである。この有芯小胞に神経ペプ チドが局在することは, 電顕レベルの免疫染色で著 者らにより実証されている ${ }^{24)}$ 。また, シナプス部は, 神経終末部に局在せず神経突起の至る所に分布して いる。また, 前部にも後部にもシナプス小胞が存在

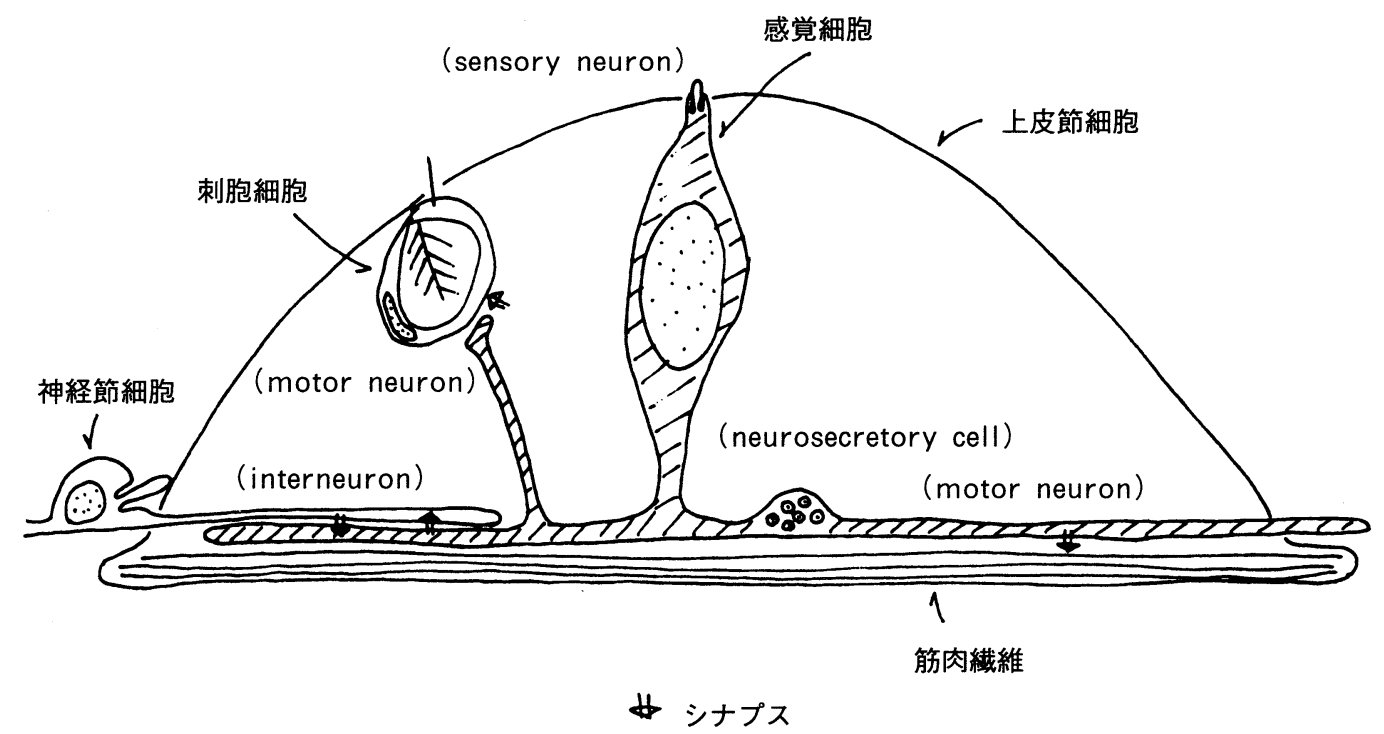

図 1 ヒドラの神経系の模式図 触手の感覚細胞の場合について示している。感覚細胞は, 触手の 上皮筋細胞に包まれていて, 外界に感覚性の繊毛を出し(感覚ニューロン), 他の神経細胞の神経突 起とシナプス結合し(介在ニューロン), また, 上皮細胞の筋肉繊維にもシナプス結合し(運動ニュー ロン), 同時に, 同じ細胞が他の効果器(刺胞細胞)にもシナプス結合し, 分泌顆粒の集中も見られ る(神経分泌細胞)。このようにヒドラの神経細胞は, 一つで, 全ての機能をカバーしている。(小 泉原図） 
する対称シナプスも良く見られる。gap junction は上皮細胞の筋肉部には必ず見られるが, 神経細胞 同士は稀である。

図 1 は, 触手の感覚細胞の模式図である ${ }^{32)}$ 。細胞 体の頂端部に感覚性の繊毛を持ち, 筋肉層ともシナ プス結合が見られ, 他の神経細胞の細胞体や神経突 起にもシナプスをしている。更に, 同じ細胞が異種 の効果器, 刺胞細胞にもシナプスしている。また, 神経突起の一部が肥大してそこに分泌顆粒が集中し, 神経分泌細胞のバリコシティーと同様の構造を示し ている。なおこの分泌顆粒は, シナプス小胞の有芯 小胞と形態はほぼ同様である。

神経節細胞も, 繊毛が伸びる部位が, 細胞体の基 部の違いはあるにしても, 基本的には, 図 1 と事情 は一緒である。

即ち, ヒドラの散在神経系では, 全ての神経細胞 が感覚ニューロン・運動ニューロン・介在ニューロ ン・神経分泌細胞の機能を同時に担っていると思わ れる。

神経細胞の密度は, 頭部が一番高く, ついで足部, 胴体部が一番低いというように, 神経細胞の分布は 体全体に均一ではない。密度を 1 つの上皮細胞当た りの神経細胞の数 $(\mathrm{Nv} / \mathrm{Ep})$ で示すと, 胴体部で $1 / 6$, 足部, 触手で 1 , 口丘で 2 である ${ }^{5)}$ 。また, この単 純な神経系も沢山の部分集合を含む。神経ペプチド の抗体や神経細胞に特異的な単一クローン抗体によ る抗体染色で, 色々な表現型を発現した神経部分集
合が可視化できる。その結果，ヒドラの神経網は沢 山の部分集合のモザイクで, そのモザイク模様がい つも一定に維持されていることが分かる。そして， 神経網のパターンも, 身体の各部で異なった様子を 示す ${ }^{13.22) 。}$

単純な神経系と言えども, 高等動物と同様, 一個 体の中で神経細胞は大変な多様性を示し, 体の各部 で多様な機能を営んでいる可能性をうかがわせる。

図 2 には，ヒドラで観察された各種神経細胞の分 布図を示している。体全体に見られる神経節細胞の ネットに, 口丘・触手・足盤の感覚細胞, 口丘には 神経環, 胴体部には非常に長い神経突起を持った神 経節細胞などがある。これらが, 外胚葉上皮細胞の 一層に重なって存在している。

\section{3. 散在神経系の機能}

構造的に神経細胞の集中が見られず，全ての神経 細胞が何でも屋であるこのヒドラの散在神経系の機 能は, どの程度のものであろうか。

その点を細胞レベルで見ると, 電気伝導(神経纎 維での活動電位の発生とその伝導)や化学伝達(シナ プス部位での化学伝達物質とその受容分子による情 報伝達)などの神経系としての基本的な機能はそろっ ている11。

それでは, 行動レベルの機能はどうか。それも以 前考えられていたよりも,ずっと複雑である。
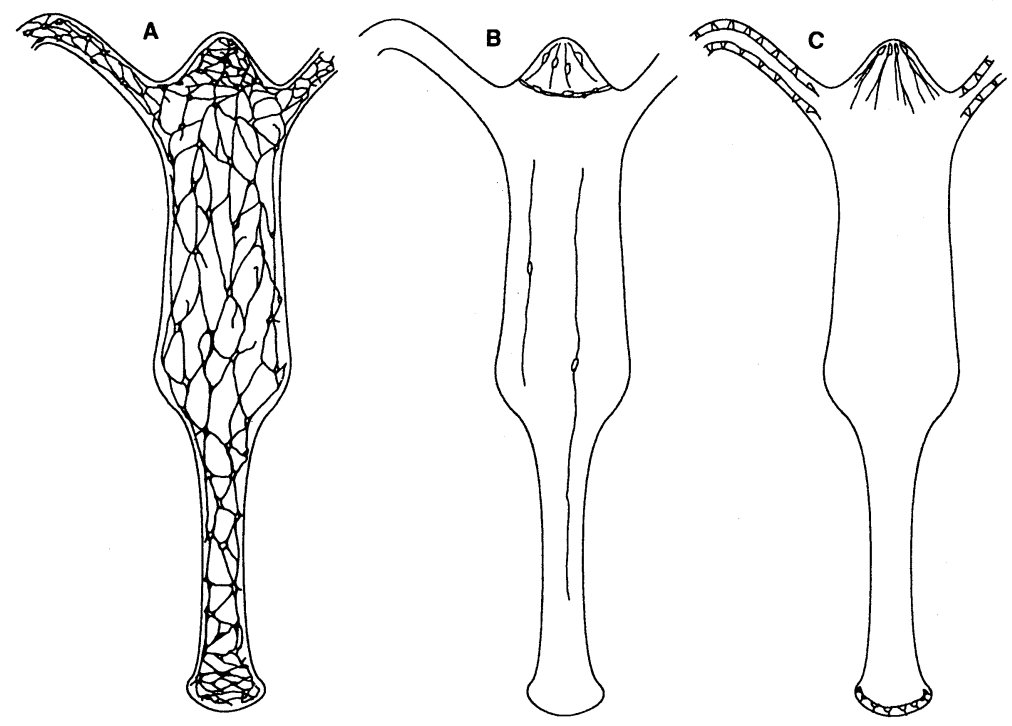

図 2 ヒドラの神経網の模式 図外胚葉の各種の神経細胞 を3つに分けて示してある。 神経節細胞が体全体の神経ネッ 卜を作り $(\mathrm{A})$ ，それに感覚細 胞が加わり $(\mathrm{C})$, 更に特殊な 神経細胞群 $(\mathrm{B})$ も取り込まれ ている。(小泉原図) 
たとえば, ヒドラの移動の行動様式についてみても 非常に多様である。ヒドラは, 通常は固着生活をし ているが, 色々な場面で移動行動を行う。素早いと んほ返り行動, しゃくとり虫様運動, 固着したまま の足部による移動, 触手を利用した移動(触手を床 にくっつけて移動), 水表面の表面張力を利用した 移動, 足部より気泡を発生させその気泡を利用した 大移動と移動後の気泡をはずしてのダイビングなど, 色々な場面で様々な移動様式を選択している ${ }^{27)}$ 。

更に, 集中神経系では中枢神経系が関与している 中枢機能が, 散在神経系でも見られる。たとえば, 飽食による捸食閾値の上昇など様々な飽食による行 動修飾である ${ }^{2,12,21)}$ 。飽食したヒドラが更にエサを 食べる場合には, 口丘の部分に首のようなくびれを 作って，エサを取り込む。このような「くびれ形成 (neck formation)」は, 絶食ヒドラでは決してみら れない。しかし，絶食ヒドラにも胃腔内にチロシン を注入し, 体外に摂食化学刺激であるグルタチオン を加えると, くびれ形成が見られる。この場合, 胃 腔内の体内チロシン受容器と体外からの刺激を受け 取るグルタチオン受容器からの両者の感覚入力の 統合によって，この行動が発現していると思われ

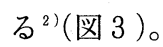

このような複数の感覚入力を統合して行動を決定 する能力に加え, 学習の原始的な形態である慣れ (habituation)の現象も観察されるという報告もあ る。動物は, ある刺激に反応して報償を得るとその 刺激に対する反応は強められ, 逆に罰を得ると弱め
られ，何もなければその刺激を無視するようになる。 この最後の場合を慣れと呼び, 中枢神経系の機能で あることが判明している。

ヒドラも触手に加えられる機械刺激の繰り返しに よって, ついには収縮反応をしなくなり,これが筋 肉の疲労ではなく, 感覚器の順応でもないことが行 動学的に示されている ${ }^{26)}$ 。

このように散在神経系も高等動物の中枢機能に対 応する能力を持つことが分かる。たた，連合学習の 能力はまだ誰も証明していない。散在神経系のハー ドウエアーでは連合学習は無理なのかもしれない。

同時に, これらの中枢機能を調べてゆくと散在神 経系独特の特徵も見られる。ヒドラのグルタチオン に対する触手の摂食反応は, 個体から切り離された 触手でも同様に見られる。そして, 飽食個体の触手 は, 個体より切り離されても, グルタチオンに対し て反応しない。飽食による摂食反応の抑制機構が, 個々の触手に存在するようである (図 4$)^{12)}$ 。このよ うに, 神経機能の地方分散的な性質も顕著である。

\section{4. 散在神経系の形成(発生神経生物学)}

ヒドラの散在神経系は, 神経細胞の発生動態にお いて特徵的な性質を示す。神経細胞が非常に活発な 発生動態を示す。成熟個体においても神経細胞は多 分化能幹細胞である間細胞より分化・生産され続け ている。同時に, 体の先端部より消失し続けている (若い出芽体の方に供給される分もある)。このよう

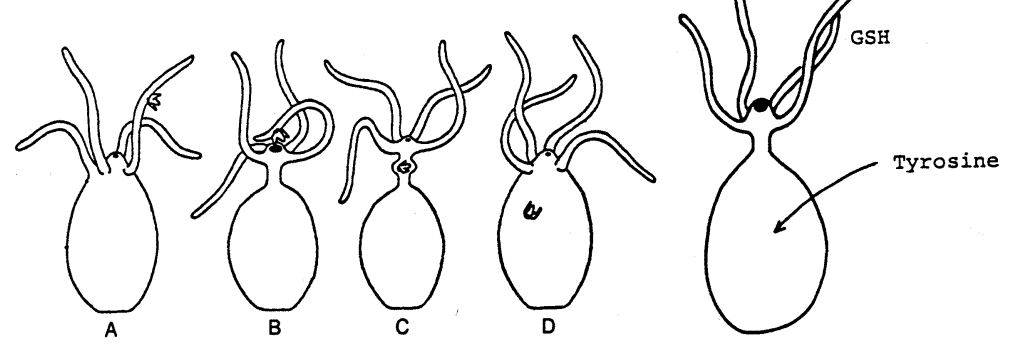

図 3 飽食ヒドラの示すくびれ形成 飽食したヒドラが更にエサを取 り込む時は，口丘のしたに首のようなくびれを作ってエサを取り込む。 A から D はくびれ形成の時間経過を示し，B，Cがくびれ形成を示す。 この行動は, 胃腔にチロシンを注入し, 外にグルタチオンを添加する と飢餓ヒドラでもくびれ形成を引き起こすことができる(右図)。 (Blanquet \& Lenhoff, 1968より改変)

Vol. 16, No. 4 (1999) 
A

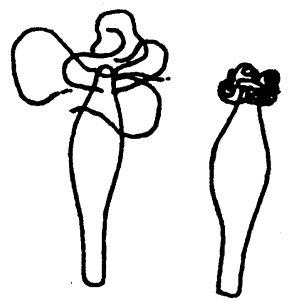

絶食ヒドラ

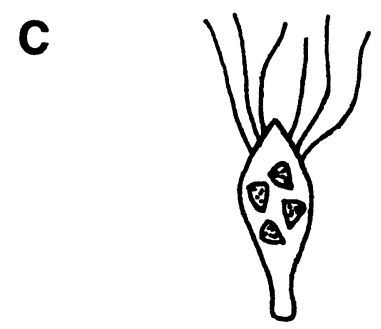

飽食ヒドラ
B

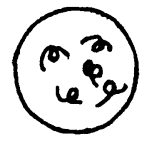

絶食ヒドラからの切断触手

D

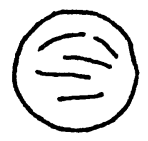

飽食ヒドラからの切断触手
図4 摂食制御の分散的制御を示す実 験の模式図 図は，全て摂食化学刺激 グルタチオン存在下の様子を示してい る。絶食ヒドラから切り出した触手 (B) も，絶食個体の無傷の触手 $(\mathrm{A})$ と 同じようにグルタチオンに対して摂食 反応を行う。飽食により損食化学刺激 の閾值が上がり，飽食ヒドラの触手は グルタチオンに対して反応しなくなる (C)。この飽食ヒドラから切り出した 触手は, グルタチオンに対して反応し ない $(D)$ 。即ち, 触手のみで飽食によ る抑制が見られ，一本の触手に摂食制 御の機構が存在することがわかる。 (小泉原図)
な生産と消失のバランスの上に, ヒドラの一定の神 経密度が保たれている。

そのため, 神経細胞は上皮細胞とともに体内の位 置を中心部から先端部へ変え続けている。しかしこ のような継続的な神経細胞の転移にもかかわらず, 様々な表現型を示す神経部分集合の個々の分布は一 定である。神経細胞の継続的な転移にも関わらずた くさんの部分集合よりなる神経モザイク模様は一定 に保たれている。

このことに関しては, 私たちは神経細胞の位置に 依存した表現型の変化 (neurotransmitter phenotypic plasticity)を提唱している ${ }^{3,7,13,17-19,22)}$ 。

このようにヒドラの神経系は活発な発生動態を示 す。

\section{4 - 1. 多様な実験系における神経網形成}

神経系の活発な発生動態, 強い再生力, 個体レ ベルの操作に対する強い耐性などの性質のため, ヒ ドラには神経網形成を研究する上で有利な特徴が見 られる。それは, 神経網形成を調べるとき通常の胚 発生系以外に様々な実験系を使うことができること である ${ }^{13-16,23) 。 ~}$

その実験系とは, 例えば, 再生系・出芽系・再導 入系・正常成熟系・解離再集合系などである。ヒド ラでは頭部を切除すると数日の内に頭部組織が再生 してくる。同時に頭部の神経網も再現してきて, 攝
食行動のような機能も回復してくる。これが再生系 である。

ヒドラは無性生殖の出芽と言う方法で増殖する。 成熟個体の胴体の一部の突起が新しいヒドラになる。 この時に,それぞれの体の部位に対応した神経網が できる。これが出芽系である。

ヒドラでは神経細胞を全く含まない上皮細胞のみ でできた上皮ヒドラを作成・維持できる。これは自 分では摂食行動などできないし，浸透圧調節もうま く行かないので, 毎日, 胃洗浄と強制掑食が必要と なる。寝たきりヒドラと呼んで，世話は大変である が維持できる。この上皮ヒドラに間細胞を導入して, 神経細胞が全然無い上皮組織のみの状態から, 神経 網形成を観察できる。これが再導入系である。

また, ヒドラでは成熟個体でも常に神経細胞はで き続けていて,この新生神経細胞は既存の神経網に 取り込まれ続けている。この成熟個体での神経細胞 の分化・神経網形成が正常成熟系である。

また, ヒドラは一度個体全体を, 単細胞にまで解 離して，またそれを遠心で集めて肉団子にし，これ からまた個体が再生する。これが解離再集合系であ る。

これらの系で起こる神経細胞の分化・神経網形成 はそれぞれ異なった条件で進行するため, これらの 比較により, 神経網形成の制御要因を細胞レベルで 明らかにできる。我々は，そのような研究によって， 
神経網形成にとってその環境である上皮細胞の重要 性，また成熟した神経細胞からの制御などを報告し ている ${ }^{13-16,23)}$ 。

\section{4 - 2. 神経網形成の分子機構 : ヒドラのペプチド} 性シグナル分子の大規模スクリーニング

神経回路網の形成機構の上述の細胞レベルの研究 に関連して, 分子レベルの研究も行なっている。そ のひとつが,「ヒドラのペプチド性シグナル分子の 大規模スクリーニング」である。これは広島大学 . 国立遺伝研・イエナ大学との共同プロジェクトであ る。比較的原始的な多細胞生物であるヒドラから， 発生現象や生理現象など色々な生物現象において細 胞間情報伝達に関わっているシグナル分子を，ペプ チド分子に的を絞って，全てを同定しょうというプ ロジェクトである。

戦略は基本的には, 特定の生物検定系を使わず, 一つ一つ片っ端から単離・精製・構造決定・化学合 成を行って, 最後に生物活性を調べる。即ち, この 大量に化学合成されたペプチド分子を使って, 手分 けして様々な活性検定を行うというものである ${ }^{29,30,33)}$ 。 我々は既に300以上のペプチドを単離，アミノ酸配列 決定も200以上について行なっている。更に, これら のペプチドについて, 系統的に抗体作製も行ってい る。

その結果，いろいろと興味ある活性を持つペプチ
ドが見つかった。その中には，筋収縮を制御する各 種の神経ペプチドに加え, 形態形成に関連したもの, 細胞分化に関連したものも含まれる(表 1$)^{29,30,33) 。 ~}$

この細胞分化に関連したもののなかで，神経網形 成に関連したペプチドがある。それが神経細胞の分 化を促進するペプチド Hym355と, 神経細胞の分化 を抑制するペプチド同族体 $\mathrm{PW}$ ペプチドである ${ }^{29,30)}$ Hym355は抗体を用いた免疫組織化学により神経細 胞に局在する神経ペプチドであることが判明した。 $\mathrm{PW}$ ペプチドは，4種のメンバーから成り $\mathrm{C}$ 末に LPW の共通配列を持つ(一つはロイシン $(\mathrm{L})$ がイソ ロイシン (I)に変わっているが, 両者は近い)。これ は, 上皮細胞に局在する上皮ぺプチドであることが 判明した。この両者の活性は, 同時に与えると相殺 され，それぞれ異なった細胞から放出されるにも関 わらず, 神経細胞分化の制御機構において何らかの 相互作用があることが考えられる(図 5 )。

神経網の形成機構については, このように細胞レ ベルと分子レベルの研究が, うまくかみ合って解明 されることが期待される。

\section{5.神経環：中枢神経系の原型か}

このように神経細胞が常に入れ替わり, 神経細胞 の機能分化が見られず, 神経細胞の集中が見られな いヒドラの散在神経系の中で, 少し変わった, むし

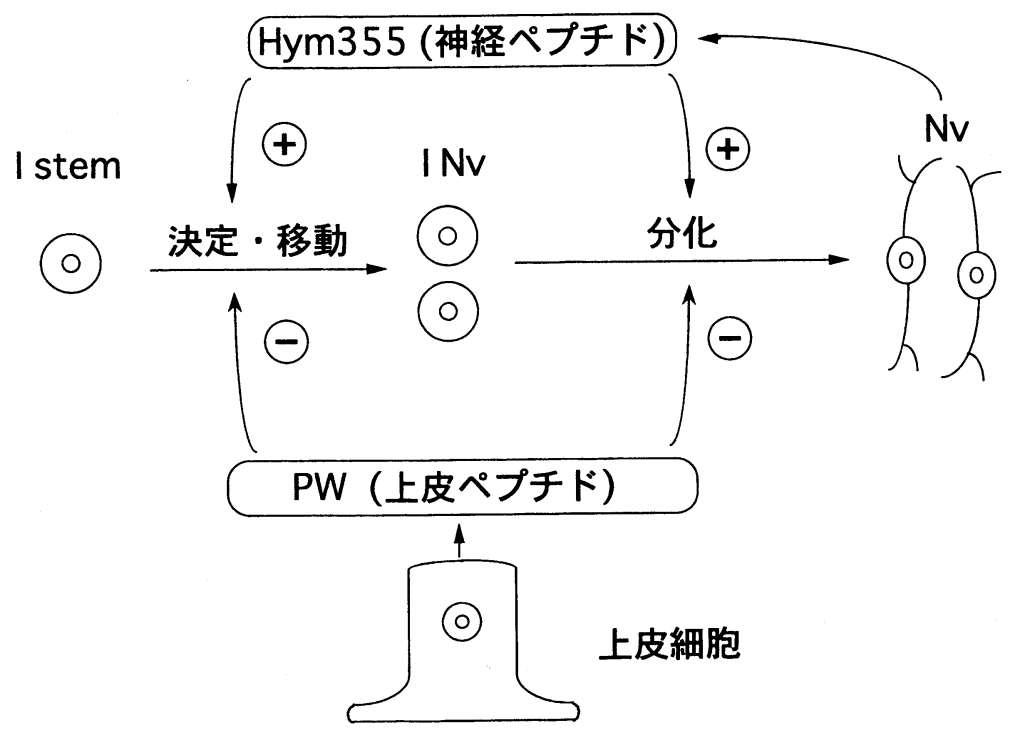

図 5 神経分化のペプチドに よる制御 ヒドラの神経幹細 胞(間細胞)から神経細胞への 分化の 2 種のペプチドによる 制御を示す。神経分化を促進 するHym355は神経ペプチド で，神経分化を抑制する LW は上皮ペプチドである。両者 の活性は，お互いに相殺しあ うため, 生産される細胞種は 異なるが, 両者の間に相互作 用があることがわかる。

Istem は幹細胞, INv は神 経細胞への分化の決定を受け た間細胞, Nvは分化した神 経細胞を示す。(小泉原図) 
表 1 ヒドラの機能ペプチド

\begin{tabular}{|c|c|c|}
\hline \multicolumn{3}{|l|}{ 形態形成 } \\
\hline \multirow[t]{2}{*}{ 足部形成 } & Hym 232 & KWVQGKPTGEVKQIKF \\
\hline & Hym 346 & AGEDVSHELEEKEKALANHS \\
\hline \multicolumn{3}{|l|}{ 細胞分化 } \\
\hline \multirow[t]{5}{*}{ 神経分化の抑制 } & \multicolumn{2}{|l|}{ PW peptides } \\
\hline & Hym $33 \mathrm{H}$ & AALPW \\
\hline & Hym 33 & EPSAAIPW \\
\hline & Hym 37 & SPGLPW \\
\hline & Hym 310 & DPSALPW \\
\hline 神経分化の促進 & Hym 355 & FPQSFLPRGa \\
\hline \multicolumn{3}{|l|}{ 筋収縮 } \\
\hline \multirow{9}{*}{$\begin{array}{l}\text { 内胚葉 } \\
\text { 出芽放出 }\end{array}$} & Hym 176 & APFIFPGPKVa \\
\hline & \multicolumn{2}{|l|}{ LWamide peptides } \\
\hline & Hym 53 & NPYPGLWa \\
\hline & Hym 54 & GPMTGLWa \\
\hline & Hym 248 & EPLPI $\overline{\text { GLWa }}$ \\
\hline & Hym 249 & KPIPGLWa \\
\hline & Hym 331 & GPPPGLWa \\
\hline & Hym 338 & GPPhPGLWa \\
\hline & Hym 370 & KPNAYKGKLPIGLWa \\
\hline
\end{tabular}

ろ高等動物の神経系に近い神経構造が見られた。そ れが, ヒドラの口丘の回りにみられる神経環である (図 6$)^{20)}$ 。

この神経環は，食道の回りを輪状に走る双極性の 神経節細胞の神経突起がお互い集まって神経束を作っ ている。そして，上皮組織の継続的な転移の中で, この神経環を含む上皮組織のみは, 転移のない定常 帯であり, 神経細胞の入れ替わりも非常にゆっくり である。

この神経環は，1)原始的ながら神経細胞の集中が 見られること，2)神経細胞の発生動態が高等動物に 近いこと，3)口あるいは食道をとりまく神経構造で あること, を考えると, 原始的な中枢神経系かもし れない。基本的には, 後口動物も前口動物も, 下等 無脊椎動物の中枢神経系は, 口あるいは食道をとり まく神経環である。

ヒドラの行動学的機能を考えると,たくさんの中 枢機能が観察できるし，それに対応した神経構造が 神経環かもしれない。

\section{6. 神経系の起源と進化}

生物の進化は一度きりの歴史であるから，そこに は多くの偶然的要素もあり, 実験的検証も容易では なく, 分子進化学の盛んな現在でもこれを解明する のは想像以上に難しい。しかし, 現存する多様な神 経系の構造と機能の関係を比較検討し，それぞれの 神経系間の関係を理解することは, 一つの神経系を 媣く理解しょうとする時にも, 有効なものと思われ る。更に, 研究対象の神経系がどのように機能して いるかという問いと同時に, それが, なぜ・どのよ うにしてその様な機能・戦略・機構を持つにいたっ たかの疑問に対する答えを持つことは, 神経系に対 する理解を格段に深めるであろう。そのためには, 多様な神経系を比較検討し, 神経系の進化の過程ま で考察してみることは価值があることと思われる。

\section{6-1. 神経伝達物質の起源と進化}

ヒドラの神経系でペプチドが神経伝達物質として 機能している証拠は, 様々なレベルで存在する。し 


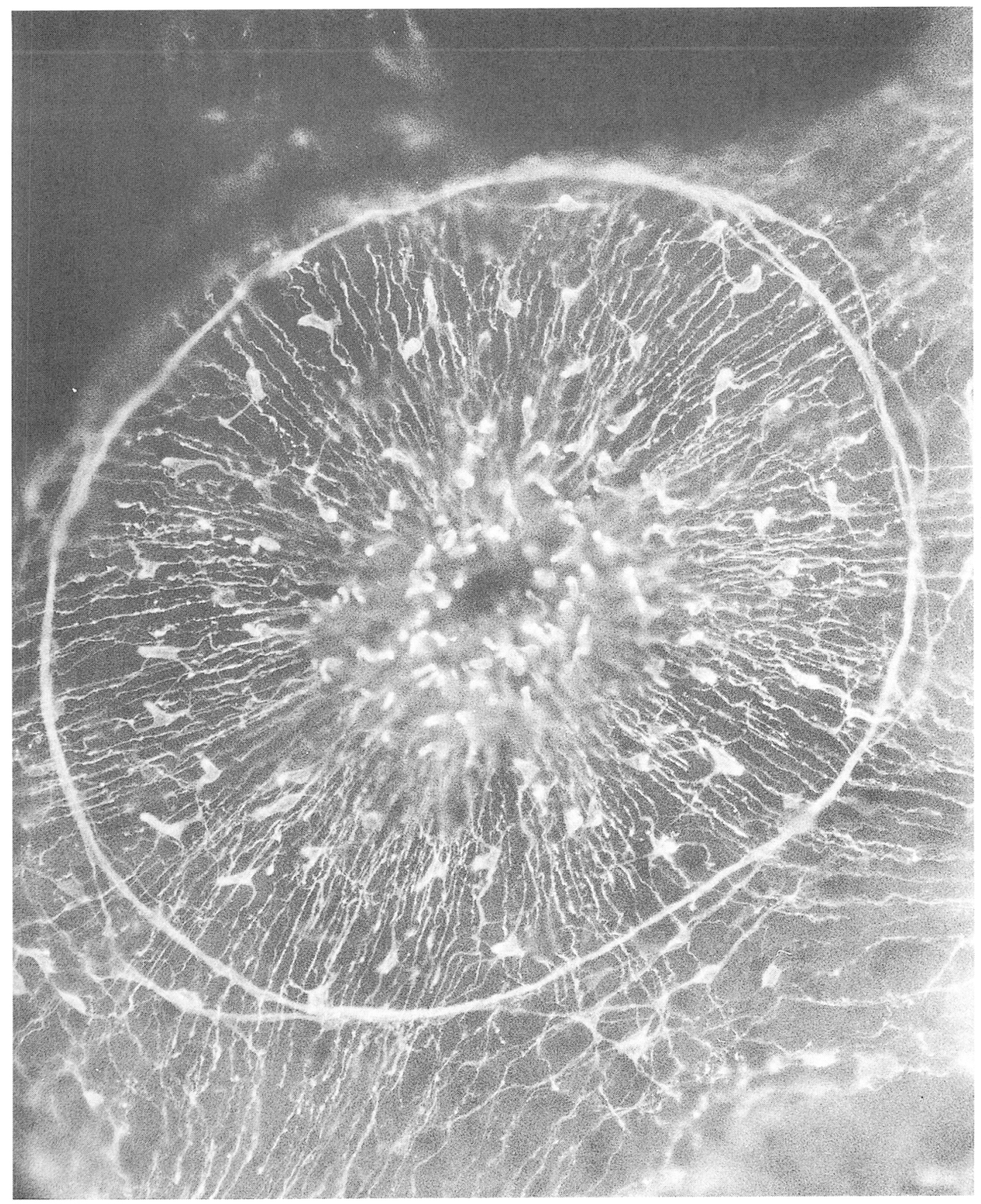

図 6 ヒドラのロ丘に見られる神経環の写真 神経ペプチド RFamideの抗体を用いた免疫染色に よって頭部の神経網が可視化されている。神経環は双極の神経節細胞同士が神経突起の束を作って いるため，他の部位の神経細胞の神経突起より太い神経束を形成している。(小泉撮影) 
かし,アセチルコリンやモノアミンやアミノ酸類な どの古典的伝達物質についてはどうであろうか。ヒ ドラでは, コリン作動性ニューロンが存在する証拠 はなく, むしろ否定的である ${ }^{10)}$ 。この事情は, 腔腸 動物の散在神経系全体について見られる ${ }^{28)}$ 。モノア ミンについては, 散在神経系全体をみると, 発光反 応などに関連して神経伝達物質として機能している 例は一部ある ${ }^{1,25,31) 。 し か し ヒ ト ゙ ラ に つ い て は ， ま た ゙ ~}$ 良く分からない。アミノ酸類についても同様である。 高等動物では, 神経伝達はコリン・モノアミン・ アミノ酸などの古典的伝達物質が主たる機能を担い, その脇役として, ペプチドが考えられている。ペプ チドは, 神経伝達を様々に調節する神経修飾物質と して働いていると考えられてきた。しかし，ヒドラ の場合を考えると, 神経伝達物質の起源はぺプチド だと思える。そうすると, ペプチドの働きの多様性 の意味が見えてくる。神経系は, 最初は DNA/夕 ンパク質系を使って神経ペプチドを合成し，多様な 神経伝達機能を行っていた。その後で,アミノ酸を 出発とした新しい代謝系が付け加わり, 古典的な伝 達物質が現れた。これらは, もっぱら, 高速で高効 率の伝達を担う要請のもと現れ，機能するようになっ た。

ヒドラから見ると, 神経伝達物質の起源と進化に 関しては以上のような仮説が浮かび上がってくる。

\section{6-2. 神経系の起源と進化}

神経系は集中化と分業化の方向に進化したと言わ れる。それは, ヒドラの散在神経系から他の神経系 を眺めると良く理解できる。散在神経系は, 基本的 には特殊に神経細胞の集中した部位がなく, 散在神 経網が体を被っている。神経細胞の機能の特殊化は 進んでおらず, 神経細胞は全ての神経機能をカバー する。

同時に,ヒドラの神経細胞は, 常に細胞分化が起 こり, 細胞は常に入れ替わっている。神経組織が損 傷を受けるとすぐに再生による修復が可能である。 神経突起が損傷を受けると, 退行変性など起こらず ただちに神経繊維のみが修復する。

ヒドラから見ると高等動物の神経細胞はいかに特 殊化した細胞であるかが分かる。細胞分化の機能は 早期に失い, 回路の維持のために動物の寿命と同じ 長さの長期生存の戦略を取っている。細胞の極性は 極端に進み, 情報を長距離に伝える一本の極端に長 い軸索と, 情報の入力部である短い多数の樹状突起
からなる。軸索の損傷に対して退行変性のような込 み入った修復法をとり，時には全く再生能力を持た ない場合もある。

これらの神経細胞の良く知られたイメージは, 全 ての神経系にあてはまるものでは無いのである。ヒ ドラの神経細胞から考えると, 神経細胞も最初はよ り一般性の高い細胞から，より特殊化した細胞へ変 化していった様子がうかがわれる。

\section{7.おわりに}

神経系や脳の理解のためには, 神経回路の作動原 理を探る神経生理学的研究と共に, それを可能にす る神経系の構造の神経解剖学と, それを形成する仕 組みを知る発生神経生物学の理解が必要である。ま た, この構造・機能・発生の軸は, 分子・神経細胞· 神経組織・器官の各階層を貫いていて, 更にそれに 進化の軸が加わる。それらの全ての側面について, 全てのレベルで総合的に攻めて初めて神経系の本当 の理解が出来ることと思う。細胞レベルと神経細胞 同士が神経情報による相互作用をするレベルでは全 く異なる法則が現れてくるように, 細胞レベルから 分子レベルへの還元的な思考も，更に上のレベルへ の統合的な思考も両方同時に必要である。

ヒドラの散在神経系は，この総説で見てきたよう に, 神経系としての共通性と, 散在神経系ならでは の独自性も持ち合わせていた。その視点から高等動 物の神経系を眺めると, その特殊性も明確に見えて きた。ヒドラの神経系は系統樹の上でもユニークで 重要な位置にいる。また, ヒドラは, 発生生物学の知 見が豊富で細胞レベル・個体レベルの実験手法に関 しては多くの有利さを持っている。それにもかかわ らず, ヒドラの神経生物学に関わっている研究者は 少ない。一人の若者でも,この総説によってこの分 野に入って来ることがあればこれに勝る喜びはない。

\section{文献}

1 ) Anctil, M.: Evolution of the First Nervous Systems, pp.141-155, Plenum Press (1990)

2 ) Blanquet, R.S. \& Lenhoff, H.M.: Science, 159, 633-634 (1968)

3 ) Bode, H.R.: Trend. Genetics, 8, 279-284 (1992) 
4 ) Bode, H.: J. Cell Sci., 109, 1155-1164 (1996)

5 ) Bode, H., Berking, S., David, C., Gierer, A., Scaller, H., \& Trenkner, E.: Wilhelm Roux's Arch. Entwicklungsmech. Org., 181, 269-285 (1973)

$6)$ Bode, H.R. \& David, C.N.: Prog. Biophys. Mol. Biol., 33, 189-206 (1978)

7 ) Bode, H., Dunne, J., Heimfeld, S., Huang, L., Javois, L., Koizumi, O., Westerfield, J. \& Yaross, M. : Curr. Topics Dev. Biol., 20, 257-280. (1986)

8 ) David, C.N. \& MacWilliams, H.: Proc. Natl. Acad. Sci. USA, 75, 886-890 (1978)

9 ) A. ギーラー：サイエンス(日経新聞社)，19752, 30-42 (1975)

10) Grimmelikhuijzen, C.J.P., Graff, D., Koizumi, O. \& McFarlaneI, D.:Evolution of the First Nervous Systems, pp.95-109, Plenum Press (1990)

11) Josephson, R.K.: Coelenterate Biology, pp 245-280, Academic Press (1974)

12）小泉 修: 摂食行動のメカニズム, pp147-166, 産業図書 (1982)

13）小泉 修: Annual Review 細胞生物学 1994, pp95-106, 中外医学社 (1994)

14）小泉 修:ブレインサイエンス最前線' 95 , pp118131，講談社サイエンティフィク (1994)

15）小泉 修: 遺伝, 50, 38-44（1996）

16）小泉 修: 脳の科学, 20, 1213-1218（1998）

17) Koizumi, O. \& Bode, H.R.: Dev. Biol., 116, 407-421 (1986)

18) Koizumi, O. \& Bode, H.R. : J. Neurosci., 11, 2011-2020 (1991).

19) Koizumi, O., Heimfeld, S. \& Bode, H.R.: Dev. Biol., 129, 358-371 (1988)

20) Koizumi, O., Itazawa, M., Mizumoto, H.,
Minobe, S., Javois, J.C., Grimmelikhuijzen, C.J.P. \& Bode, H.R.: J. Com. Neurol., 326, 7-21 (1992)

21) Koizumi, O. \& Maeda, N.: J. Comp. Physiol., 142, 75-80 (1981)

22）小泉 修, 美濃部純子 : 脳腸ホルモン学会ニュー ス, 6(3), 1-5 (1991)

23) Koizumi, O., Mizumoto, H., Sugiyama, T. \& Bode, H.R.: Neurosci. Res., 13, 165-170 (1990)

24) Koizumi, O., Wilson, J.D.,

Grimmelikhuijzen, C.J.P. \& Westfall, J.A.:

J. Exp. Zool., 249, 17-22 (1989)

25) Pani, A.K., Anctil, M., \& Umbriaco, D.: J. Exp. Zool., 272, 1-12 (1995)

26) Rushforth, N.B.: Invertebrate Learning, pp 123-169, Plenum Press (1973)

27) Rushforth, N.B.: Biology of Hydra, pp 341, Academic Press (1973)

28) Scemes, E.: Evolution of the First Nervous Systems, pp.157-166, Plenum Press (1990)

29）高橋俊雄, 藤沢敏孝：遺伝，53(7)，65-70 (1999)

30) Takahashi, T., Muneoka, Y., Lohmann, J., de Haro, M., Bosch, T., David, C., Bode, H., Koizumi, O., Shimizu, H., Hatta, M., Fujisawa, T., \& Sugiyama, T.: Proc. Natl. Acad. Sci. USA 94, 1241-1246 (1997)

31) Umbriaco, D., Anctil, M., \& Descarries, L.: J. Comp. Neurol., 291, 167-178 (1990)

32) Westfall, J.A. \& Kinamon, J.C.: J. Neurocytol., 7, 365-379 (1978)

33) Yum, S., Takahashi, T., Koizumi, O., Ariura, Y., Kobayakawa, Y., Mohri, S. \& Fujisawa, T.: Biochem. Biophys. Res. Comm., 248, 584-590 (1998) 